\title{
Marine free-living nematodes in semiarid inland waters
}

\author{
Nematoda marinho de vida livre em águas continentais no semiárido
}

\author{
Fábio Lucas de Oliveira Barros ${ }^{1 *}$ (D), Maria Cristina da Silva² (D), \\ Francisco José Victor de Castro $^{2}$ (D) and Miodeli Nogueira Júnior ${ }^{1}$
}

\begin{abstract}
${ }^{1}$ Departamento de Sistemática e Ecologia, Universidade Federal da Paraíba - UFPB, Cidade Universitária, CEP 58051-900, João Pessoa, PB, Brasil

${ }^{2}$ Laboratório de Meiofauna - Labmeio, Centro de Educação e Saúde, Universidade Federal de Campina Grande - UFCG, Olho D’Água da Bica, CEP 58175-000, Cuité, PB, Brasil

*e-mail: fabio.barrosnp@gmail.com
\end{abstract}

Cite as: Barros, F. L. O., Silva, M. C., Castro, F. J. V. and Nogueira Júnior, M. N. Marine free-living nematodes in semiarid inland waters. Acta Limnologica Brasiliensia, 2021, vol. 33, e15.

\begin{abstract}
Aim: This study reports the occurrence of five Nematoda genera previously considered as exclusively marine in inland waters. Methods: Sediment samples were taken, weekly, during nine weeks, at a small spring at the Horto Florestal Olho D’Água da Bica, Cuité, PB, ca. $130 \mathrm{~km}$ away from the shoreline, between March and May 2016 and fixed in 4\% formalin. Nematodes were sorted by manual elutriation through sieves with 0.5 and $0.045 \mathrm{~mm}$ and slides were prepared. Results: The sediment was classified as coarse sand, with organic matter content ranging between 2.73 and $13.32 \%$, temperature between $27-28^{\circ} \mathrm{C}$ and constant salinity of 6 . From 315 nematodes were sampled among which 18 were from five genera previously thought to be exclusively marine were found. Bolbolaimus was the most common, found in $11.1 \%$ of the samples, followed by Gomphionema (3.7\%), Rynchonema (7.4\%), Prorynchonema (7.4\%) e Sabatieria (3.7\%), representing 5.7\% from total of nematofauna. These genera are widely distributed worldwide, but had never been recorded from inland environments. Conclusions: This study contributes with the distributional knowledge of free-living nematodes. From literature data, these genera are not restricted by low salinity, and can be found in estuarine and/or brackish water environments and body water with direct connection to the sea. In any case, the presence of marine genera in this region which is $>130 \mathrm{~km}$ away from the nearest shoreline is noteworthy, highlighting the importance of studying nematodes from these poorly known semiarid water bodies. These new occurrences raise questionings about the dispersal mechanisms that certified the colonization of these nematodes in the semiarid.
\end{abstract}

Keywords: meiofauna; nematofauna; distribution, taxonomy and ecology.

Resumo: Objetivo: Esse trabalho relata a ocorrência de gêneros de Nematoda, que eram previamente considerados restritos a ambientes marinhos, em águas continentais. Métodos: Amostras de sedimentos foram coletadas semanalmente, durante nove semanas, entre março e maio de 2016 no Horto Florestal Olho D'Água da Bica, Cuité, PB, cerca de $130 \mathrm{~km}$ da região costeira mais próxima e fixados em formol $4 \%$. Os Nematoda foram separados por elutriação manual através de peneira de malha de 0,5 e 0,045 mm e lâminas foram confeccionadas. Resultados: $\mathrm{O}$ sedimento foi classificado como areia grossa, com teor de matéria orgânica variando entre 2,73 e 13,32\%, temperatura entre 27 $28^{\circ} \mathrm{C}$ e salinidade constante de 6 . Dentre 315 nematoides coletados, 18 sáo de cinco gêneros marinhos. Bolbolaimus foi o mais frequente, presente em $11,1 \%$ das amostras, seguido de Gomphionema (3,7\%), Rynchonema (7,4\%), Prorynchonema (7,4\%) e Sabatieria (3,7\%), representando 5,7\% do total da nematofauna. Esses gêneros têm ampla distribuição no mundo, mas não possuem registros prévios 
em ambientes continentais, sendo a primeira ocorrência nesse estudo. Conclusóes: Este trabalho contribui com o conhecimento da distribuição de Nematoda de vida livre. De acordo com os dados de literatura, esses gêneros não possuem restriçóes a baixas salinidades, sendo encontrados em regiôes estuarinas e/ou águas salobras e também em corpos de água doce com conexão direta com o mar. Ainda assim, é notável a presença de gêneros marinhos há $-130 \mathrm{~km}$ de distância da costa, enfatizando a importância de estudos em diferentes corpos d'água no semiárido, permitindo questionar sobre quais mecanismos de dispersão permitiram esses indivíduos colonizar essa região.

Palavras-chave: meiofauna; nematofauna; distribuição; taxonomia e ecologia.

Free-living Nematoda are abundant in marine, freshwater and terrestrial environments (Bongers \& Bongers, 1998; Bhadury et al. 2006; Leduc $\&$ Rowden, 2018). There are around 30,000 free-living nematode species currently described, with appraisals suggesting from 1 to 100 million species to be described (Lambshead, 2003; Blaxter, 2011; Zhang, 2013; Smythe et al., 2019). Until de beginning of the last decade $\sim 2270$ genera from 256 families had been described worldwide (Hodda, 2011), with 78 genera and -220 species recorded from Brazil (Venekey, 2017). Most of the studies dealing on aquatic free-living nematodes were performed on marine environments and inland ecosystems have been mostly neglected (Traunspurger et al., 2020). Although the number of studies on continental nematodes is growing, they are concentrated on the northern hemisphere, mostly in Europe (Abebe et al., 2008; Traunspurger et al., 2020). Studies dealing on inland water nematodes from Brazil are still very sparse, mostly available in grey literature with a few published papers (e.g., Lucena et al., 2015; Barros et al., 2020; Pinto et al., 2021). Currently, there are 132 genera of freshwater nematodes record on Brazil (Pinto et al., 2021), but this number is certainly underestimated considering both the high nematode diversity (e.g., Zhang, 2013) and the lack of studies. In the current study we report five nematode genera from inland waters which were previously known as exclusive from marine environments. These findings highlight the need of increasing the knowledge of the diversity of free-living nematodes from inland water bodies worldwide and particularly at Brazil.

The material was sampled between March and May 2016 in a permanent small spring at Horto Florestal Olho D'Água da Bica, at Cuité County (6²9'06”S; 3609'24”W), Paraíba State, in the Brazilian semiarid, located ca. $130 \mathrm{~km}$ from the coastline. The reservoir has an area $-230 \mathrm{~m}^{2}$, with $2 \mathrm{~m}$ of maximum depth, and is preserved by the Campina Grande Federal University (Universidade Federal de Campina Grande, UFCG).

Weekly samplings were performed between 24 March and 12 May 2016 in the margin of the pond.
At each of the nine weeks three replicate sediment samples were taken with a $7 \mathrm{~cm}^{2}$ corer $10 \mathrm{~cm}$ deep. The material sampled was immediately fixed in $4 \%$ formalin. In addition, sediment samples were taken and frozen to perform standard granulometric and organic matter analyses in the laboratory (Suguio, 1973; Walkley \& Black, 1934). Water temperature and salinity were measured using a digital (Alfakit, AT-160, Florianopolis, Brazil) and manual field refractomer, respectively. In the laboratory, the samples were manually elutriated in sieves with meshes of 0.5 and $0.045 \mathrm{~mm}$. The material retained in the finer sieve was placed in Dollfus plates and taken to the compound microscope where all nematodes were sorted and permanent slides were made (following Cobb, 1917). The slides were taken to the optical microscope and the genera were identified following mostly Platt \& Warwick (1983), Warwick et al. (1998) and Zullini (2010). Voucher slides with the genera reported here were deposited in the Coleçáo de Invertebrados Paulo Young (CIPY), from Paraíba Federal University (Universidade Federal da Paraíba - UFPB) - CIPYNema 5-9.

The organic matter content ranged from 2.73 and $13.32 \%$, and sediment size from 0.8 to $0.97 \mathrm{~mm}$ being characterized as coarse sand (Suguio, 1973; Walkley \& Black, 1934). Temperature was nearly constant, between $27-28^{\circ} \mathrm{C}$ and salinity had constant values of 6 . From 315 nematodes sampled, 18 belong to five genera previously considered as exclusively marine (Table 1), and will be detailed in this study.

\section{Bolbolaimus Cobb, 1920}

Bolbolaimus has a strongly annulated cuticle, sometimes ornamented with dots. Head not set-off. Cephalic setae close to the front end. Amphideal fovea unispiral or cryptospiral. Buccal cavity strongly sclerotized, with large dorsal tooth, denticles may be present. Pharynx with anterior peribuccal bulb and posterior oval bulb. Copulatory apparatus strongly sclerotized and with gubernacular apophyses directed dorsally or dorsocaudally (Tchesunov, 2014b; Figure 1a). 
Table 1. Free-living Nematoda genera reported in this study, their frequency of occurrence (FO; \%), number of individuals sampled (Ind.) and environmental parameters of the samples containing them. MO = organic matter content $(\%) ; \mathrm{G}=$ granulometry $(\mathrm{mm}) ; \mathrm{T}=$ temperature $\left({ }^{\circ} \mathrm{C}\right)$. Environmental parameters are presented as mean \pm standard deviation whenever appropriate; D.N= deposit number.

\begin{tabular}{cccccc}
\hline & Bolbolaimus & Gomphionema & Rynchonema & Prorhynconema & Sabatieria \\
\hline FO & 11.1 & 3.7 & 7.4 & 7.4 & 3.7 \\
Ind. & 4 & 4 & 2 & 5 & 3 \\
MO & $7.70 \pm 5.20$ & 2.72 & $7.96 \pm 5.36$ & $2 \pm 0.6$ & 2.72 \\
G & $0.64 \pm 0.23$ & 0.8 & $2 \pm 0.71$ & $0.82 \pm 0.09$ & 0.8 \\
T & $27.75 \pm 0.25$ & 28 & $27.25 \pm 0.25$ & $27.25 \pm 0.25$ & 28 \\
D.N & 6 & 7 & 8 & 9 & 5 \\
\hline
\end{tabular}

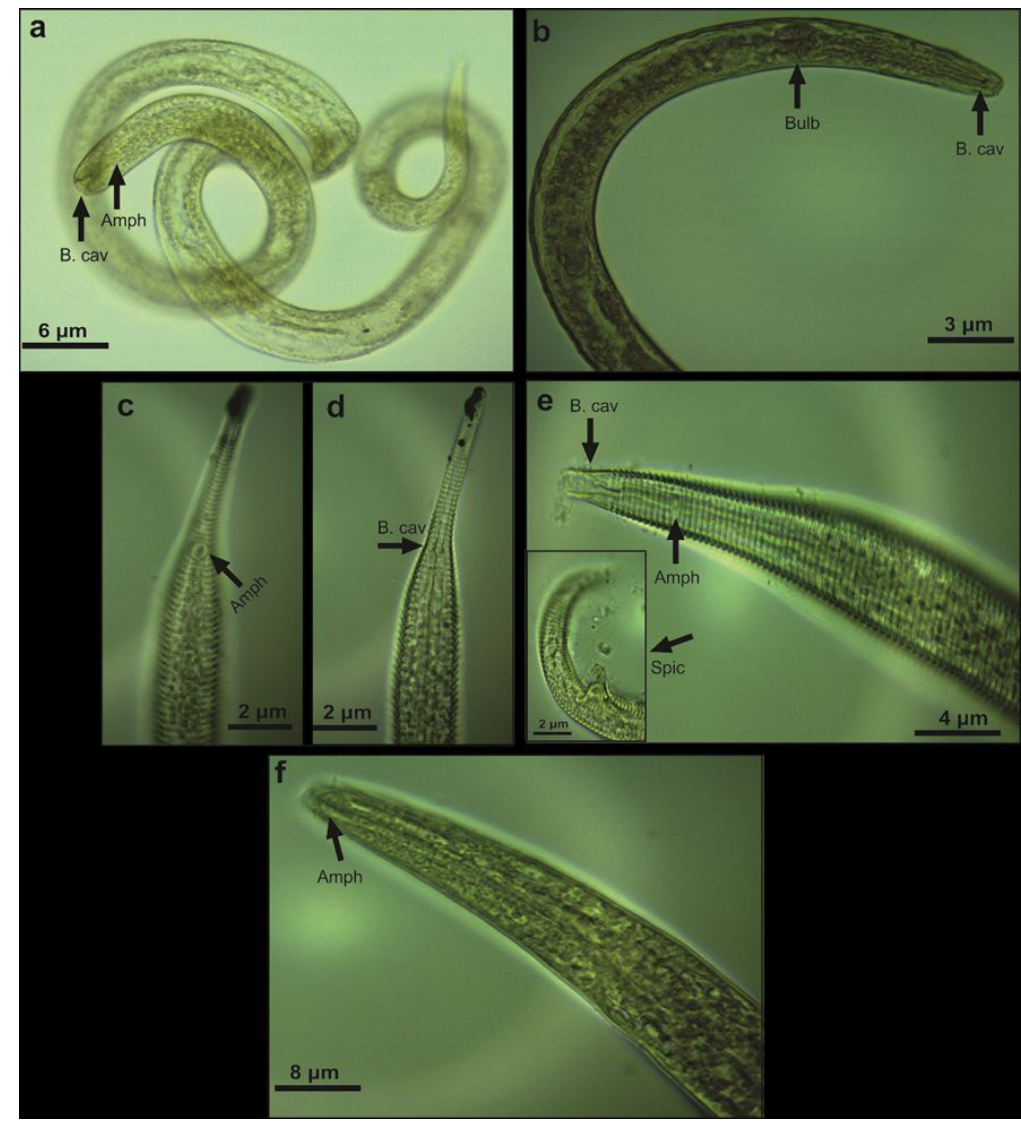

Figure 1. Free-Living Nematode genera in the Semi-Arid region. a= Bolbolaimus, b= Gomphionema, $\mathrm{c}-\mathrm{d}=$ Rynchonema, $\mathrm{e}=$ Prorynchonema, $\mathrm{f}=$ Sabatieria . Amp = Amphidio; B. cav= Buccal Cavity; Bulb= Shape of pharyngeal bulb; Spic $=$ Spicule.

This genus has been recorded between $66^{\circ} \mathrm{N}$ and $26^{\circ} \mathrm{S}$ (Muthumbi \& Vincx, 1999; Kovalyev \& Tchesunov, 2005; Hua et al., 2016; Leduc, 2016; Long et al., 2017). It currently has 11 valid species, all of them from marine environments (Bezerra et al., 2020), although it may also be found in estuarine waters in salinity between 7.07.5 (Long et al., 2017). This is the first record of Bolbolaimus from inland waters.

\section{Gomphionema Wieser \& Hopper, 1966}

Gomphionema presents buccal cavity heavily cuticularized, consisting of an anterior concave chamber and a cylindroconoid posterior portion, and armed with a massive dorsal tooth not entering the cheilostoma; subventral teeth absent. Pharyngeal bulb large, "barrel-shaped", occupying approximately one-third of the total pharyngeal length (Tchesunov, 2014a; Figure 1b).

The family Ethmolaimidae is divided into two subfamilies Ethmolaiminae and Neotonchinae this latter encompassing Gomphionema (Bezerra et al., 2013). This genus has a wide distribution, between $50^{\circ} \mathrm{N}$ and $90^{\circ} \mathrm{S}$ (Boucher \& Gourbault, 1990; Ndaro \& Ólafsson, 1999; Netto \& Gallucci, 2003; Fisher \& Sheaves, 2003; Ingole \& Singh, 2010; 
Bezerra et al., 2013; Pastor de Ward et al., 2015; Venekey \& Melo, 2016; Thai et al., 2017). There are records of the subfamily Ethmolaiminae in estuarine and inland waters, while the subfamily Neothonchinae was previously recorded only in marine waters (Bezerra et al., 2013).

Gomphionema is typically found on marine (Semprucci et al., 2013), and brackish waters from estuaries and mangroves in salinity as low as 7 (Venekey \& Melo, 2016; Thai et al., 2017). This genus currently has five species described and still is poorly studied (Bezerra et al., 2020). Both the genus Gomphionema and the subfamily Neothonchinae were not previously found in inland waters with this study being the first such record.

\section{Rhynchonema Cobb, 1920}

Rynchonema presents cuticle coarsely striated. Amphids placed over or very close to the end of the buccal tube. Buccal cavity in two parts; short anterior chamber, at the level of cephalic setae, narrow tubular part extending along the cervical region. Male with two testes. Spicules short and arcuate. Tail conical (Fonseca \& Bezerra, 2014; Figure $1 \mathrm{c}-\mathrm{d})$.

Rhynchonema has been found between $18-36^{\circ} \mathrm{N}$ and $0-40^{\circ}$ S (Jesús-Navarrete, 2003; Leduc et al., 2012; Sandulli et al., 2015; Bezerra et al., 2014; Tu \& Gagarin, 2017), and was reported from deep seawaters between 750 and $6300 \mathrm{~m}$ depth (Vanhove et al., 2004). Rynchonema was also reported from estuarine brackish waters with low salinity between 4.5-6.0 (Tu \& Gagarin, 2017).

\section{Prorhynchonema Gourbault, 1982}

Prorhynchonema possess buccal cavity in two parts; anterior short, at level of cephalic setae, posterior tubular, restricted to the anterior part of the cervical region. Amphids circular, placed well posterior to the end of buccal tube. Spicules short and arcuate. Tail conical (Gourbault, 1982; Figure 1e).

Prorhynchonema has been recorded at $16^{\circ} \mathrm{N}$ (Gourbault, 1982) and 0-80S (De Broyer et al., 2007; Venekey et al., 2010) and was reported from deep waters between 750 and $6300 \mathrm{~m}$ depth (Vanhove et al., 2004). Prorhynchonema in estuarine waters with salinity as low as 10 (Tilbert, 2017). None of these genera had been previously recorded in inland waters with this study representing the first record.

\section{Sabatieria Rouville, 1903}

The three individuals belonging to the genus Sabatieria were identified by the cuticle striated or with transverse punctuation, lateral differentiation as larger regular or irregular punctuations may occur. Anterior sensilla arranged in three crowns. Cephalic setae longer than the outer labial. Anterior portion of buccal cavity globular to cup-shaped, posterior portion narrow as a collapsed tube, weakly sclerotized; sometimes with small projections of the wall at the border between the two portions. Male excretory system with two additional uninucleate subventral gland cells far behind the cardia. Spicules usually enlarged proximally, apophyses usually directed dorsocaudally or caudally (Figure 1f). All these characteristics are consistent with those described in the review of Platt (1985).

This genus is widely distributed worldwide, between $50^{\circ} \mathrm{N}$ and $50^{\circ} \mathrm{S}$ (Chen \& Vincx, 1999; Pastor De Ward, 2003; Botelho et al., 2007; Gagarin \& Nguyen, 2008; Ansari et al., 2012; Leduc et al., 2012). It has been commonly found on marine muddy sediments where it is frequently abundant (Yang et al., 2019). Sabatieria is commonly amongst the dominant nematode genera on marine environments such as deep water (Ott et al., 1991), oceanic islands, estuaries, sand beaches and continental shelf (Vanreusel et al., 2010; Venekey et al., 2010). This genus has been found with salinity down to 1 (Adão et al., 2009), and recently recorded inside the São Francisco River (NE Brazil) relatively close $(<20 \mathrm{~km})$ and with direct connection to the sea (Pinto et al., 2021). The current record emphasizes its presence on freshwater $>100 \mathrm{~km}$ away from the coast in a body of water completely independent from the sea.

\section{Final remarks}

Apart from the five genera reported here, Pseudosteneria and Odontophoroides also were previously thought to be exclusive from marine environments but have been reported in the Brazilian semiarid (Lucena et al., 2015). It is noteworthy the presence of many marine genera in closed body of waters of this region which is $>130 \mathrm{~km}$ away from the nearest shoreline. All these genera are frequently found in estuarine brackish waters with low salinity (Adão et al., 2009; Long et al., 2017; Tu \& Gagarin, 2017). Consequently, the saline condition in many of the semiarid water bodies and inland freshwater closer seawater ( 6 in this study; 19 in Lucena et al., 2015; and <0.5 in Pinto et al., 2021) may not be a restrictive factor to the survival of these nematode genera. These observations raise questionings about the dispersal mechanisms of these tiny organisms and highlight the importance of studying 
nematodes from different semiarid water bodies. Further taxonomic studies with identification down to the species level will be important to test for endemism of these Nematoda from the Brazilian semiarid water bodies.

\section{Acknowledgements}

This study was part of the bachelorship dissertation of the first author which received support from the Conselho Nacional de Desenvolvimento Científico e Tecnológico (CNPq) and from Coordenação de Aperfeiçoamento de Pessoal de Nível Superior (CAPES) 88887.475400/202000. Also, the authors thank Dr. Márcio Frazão Chaves for helping with the photographs, and to Dra. Jessica Prata for the help with depositing the voucher slides.

\section{References}

ABEBE, E., DECRAEMER, W. and DE LEY, P. Global diversity of nematodes (Nematoda) in freshwater. Hidrobiologia, 2008, 595(1), 67-78. http://dx.doi. org/10.1007/s10750-007-9005-5.

ADÃO, H., ALVES, A.S., PATRÍCIO, J., NETO, J.M., COSTA, M.J. and MARQUES, J.C. Spatial distribution of subtidal Nematoda communities along the salinity gradient in southern European estuaries. Acta Oecologica, 2009, 35(2), 287-300. http://dx.doi.org/10.1016/j.actao.2008.11.007.

ANSARI, K.G.M.T., LYLA, P.S. and AJMAL KHAN, S. New records of free-living marine nematodes (Nematoda: Enoplida) from Indian waters. Journal of the Marine Biological Association of India, 2012, 54(2), 5-11.

BARROS, F.L.O., SILVA, M.C., VIEIRA, A.A. and CASTRO, F.J.V. Freshwater nematofauna (Nematoda) in a semi-arid region. Revista Nordestina de Zoologia, 2020, 12(2), 1-14.

BEZERRA, T.N., DECRAEMER, W., EISENDLEFLÖCKNER, U., HODDA, M., HOLOVACHOV, O., LEDUC, D., MILJUTIN, D., MOKIEVSKY, V., PENAA SANTIAGO, R., SHARMA, J., SMOL, N., TCHESUNOV, A., VENEKEY, V., ZHAO, Z. and VANREUSEL, A. Nemys: World Database of Nematodes [online]. 2020 [viewed 28 May 2020]. Available from: http://nemys.ugent.be

BEZERRA, T.N., PAPE, E., HAUQUIER, F. and INGELS, J. New genus and two new species of the family Ethmolaimidae (Nematoda: Chromadorida), found in two different cold-seep. Zootaxa, 2013, 3692(1), 7-27.

BEZERRA, T.N., SMOL, N. and VINCX, M. Two new species of Rhynchonema Cobb, 1920 from a Brazilian sandy beach. Marine Biodiversity, 2014, 44(3), 343365. http://dx.doi.org/10.1007/s12526-014-0223-6.
BHADURY, P., AUSTEN, M.C., BILTON, D.T., LAMBSHEAD, P.D., ROGERS, A.D. and SMERDON, G.R. Development and evaluation of a DNA-barcoding approach for the rapid identification of nematodes. Marine Ecology Progress Series, 2006, 320, 1-9. http://dx.doi.org/10.3354/meps320001.

BLAXTER, M. Nematodes: the worm and its relatives. PLoS Biology, 2011, 9(4), 10. https://doi. org/10.1371/journal.pbio.1001050.

BONGERS, T. and BONGERS, M. Functional diversity of nematodes. Applied Soil Ecology, 1998, 10(3), 239-251. http://dx.doi.org/10.1016/S09291393(98)00123-1.

BOTELHO, A.P., DA SILVA, M.C., ESTEVES, A.M. and FONSÊCA-GENEVOIS, V. Four new species of Sabatieria Rouville, 1903 (Nematoda, Comesomatidae) from the Continental Slope of Atlantic Southeast. Zootaxa, 2007, 1402(1), 39-57. http://dx.doi.org/10.11646/zootaxa.1402.3.

BOUCHER, G. and GOURBAULT, N. Sublittoral meiofauna and diversity of nematode assemblages off Guadeloupe Islands (French West Indies). Bulletin of Marine Science, 1990, 47(2), 448-463.

CHEN, G. and VINCX, M. Nematodes from the Strait of Magellan and the Beagle Channel (Chile): the genus Sabatieria (Comesomatidae: Nematoda) with the description of Sabatieria coomansi n. sp. Hydrobiologia, 1999, 405, 95-115. http://dx.doi. org/10.1023/A:1003752619953.

COBB, N.A. Notes on Nemas. Contribution to the Science of Nematology, 1917, 5, 117-128.

DE BROYER, C., BOUQUEGNEAU, J. M., DAUBY, P., DE RIDDER, C. and VANREUSEL, A. Biodiversity of three representative groups of the Antarctic Zoobenthos: Comparative structure, distribution and function (BIANZO), Brussels: Belgian Science Policy, 2007.

FISHER, R. and SHEAVES, M.J. Community structure and spatial variability of marine nematodes in tropical Australian pioneer seagrass meadows. Hydrobiologia, 2003, 495(1-3), 143-158. http:// dx.doi.org/10.1023/A:1025406624390.

FONSECA, G. and BEZERRA, T.N. Order Monhysterida Filipjev, 1929. In: A. SCHMIDTRAESA, ed. Handbook of Zoology: Gastrotricha, Cycloneuralia and Gnathifera. 2nd ed. HamburgGermany: De Gruyter, 2014, pp. 435-465.

GAGARIN, V.G. and NGUYEN, V.T. A new genus and three new species of free-living Nematodes from mangroves of the Red river estuary, Vietnam. Journal of Biology, 2008, 30, 3-11.

GOURBAULT, N. Nematodes marins de Guadeloupe. I. Xyalidae nouveaux des genres Rhynchonema Cobb et Prorhynchonema nov. gen. Bulletin du Muséum National d'Histoire Naturelle, 1982, 4, 1-2. 
HODDA, M. Phylum Nematoda Cobb, 1932. In: ZHANG, Z.Q., ed. Animal biodiversity: An outline of higher-level classification and survey of taxonomic richness. Zootaxa, 2011, 3148, 63-95.

HUA, E., MU, F., ZHANG, Z., YANG, S., ZHANG, T. and LI, J. Nematode community structure and diversity pattern in sandy beaches of Qingdao, China. Journal of Ocean University of China, 2016, 15(1), 3340. http://dx.doi.org/10.1007/s11802-016-2686-5.

INGOLE, B. and SINGH, R. Biodiversity and community structure of free-living marine nematodes from the Larsemann Ice Shelf, East Antarctica. Current Science, 2010, 99(10), 1413-1419.

JESÚS-NAVARRETE, A. Diversity of nematoda in a Caribbean atoll: Banco Chinchorro, Mexico. Bulletin of Marine Science, 2003, 73(1), 47-56.

KOVALYEV, S.V. and TCHESUNOV, A.V. Taxonomic review of microlaimids with description of five species from the White Sea (Nematoda: Chromadoria). Zoosystematica Rossica, 2005, 14(1), 1-16.

LAMBSHEAD, P.J.D. Marine nematode biodiversity. In: Z.X. CHEN, S.Y. CHEN and D.W. DICKSON, eds. Nematology: advances and perspectives. Nematode morphology, physiology and ecology. Wallingford: CABI Publishing, 2003, pp. 438-468.

LEDUC, D. and ROWDEN, A.A. Nematode communities in sediments of the Kermadec trench, Southwest Pacific Ocean. Deep-sea Research. Part I, Oceanographic Research Papers, 2018, 134, 23-31. http://dx.doi.org/10.1016/j.dsr.2018.03.003.

LEDUC, D. One new genus and three new species of deep-sea nematodes (Nematoda: Microlaimidae) from the Southwest Pacific Ocean and Ross Sea. Zootaxa, 2016, 4079(2), 255-271. http://dx.doi. org/10.11646/zootaxa.4079.2.7. PMid:27396004.

LEDUC, D., ROWDEN, A.A., BOWDEN, D.A., NODDER, S.D., PROBERT, P.K., PILDITCH, C.A., DUINEVELD, G.C.A. and WITBAARD, R. Nematode beta diversity on the continental slope of New Zealand: spatial patterns and environmental drivers. Marine Ecology Progress Series, 2012, 454, 37-52. http://dx.doi.org/10.3354/meps09690.

LONG, P.K., GAGARIN, V.G., TU, N.D., PHUONG, N.T.X. and THANH, N.V. Bolbolaimus obesus sp. n. (Nematoda, Desmodorida) from Mangrove Thickets in the Tien Yen River Estuary, Vietnam. The Biological Bulletin, 2017, 44(8), 844-851. http://dx.doi. org/10.1134/S1062359017080064.

LUCENA, B.K.P., SILVA, M.C. and CASTRO, F.J.V. Nematode community of continental lakes with different concentrations of salts. Revista Nordestina de Zoologia, 2015, 9(1), 2-15.

MUTHUMBI, A.W. and VINCX, M. Microlaimidae (Microlaimoidea: Nematoda) from the Indian Ocean: description of nine new and known species.
Hydrobiologia, 1999, 397, 39-58. http://dx.doi. org/10.1023/A:1003686212934.

NDARO, S.G. and ÓLAFSSON, E. Soft-bottom fauna with emphasis on nematode assemblage structure in a tropical intertidal lagoon in Zanzibar, eastern Africa: I. Spatial variability. Hydrobiologia, 1999, 405, 133-148.

NETTO, S.A. and GALLUCCI, F. Meiofauna and macrofauna communities in a mangrove from the Island of Santa Catarina, South Brazil. Hydrobiologia, 2003, 505(1), 159-170.

OTT, J.A., NOVAK, R., SCHIEMER, F. HENTSCHEL, U., NEBELSICK, M. and POLZ, M. Tackling the Sulfide Gradient: A Novel Strategy Involving Marine Nematodes and Chemoautotrophic Ectosymbionts. Marine Ecology (Berlin), 1991, 12(3), 261-279. http://dx.doi.org/10.1111/j.1439-0485.1991. tb00258.x.

PASTOR DE WARD, C., LO RUSSO, V., VILLARES, G., MILANO, V., MIYASHIRO, L. and MAZZANTI, R. Free-living marine nematodes from San Julián Bay (Santa Cruz, Argentina). ZooKeys, 2015, 489, 133-144. http://dx.doi.org/10.3897/ zookeys.489.7311. PMid:25878534.

PASTOR DE WARD, C.T. Two new species of Sabatieria (Nematoda, Comesomatidae) from Golfo Nuevo, Chubut (Argentina). Zootaxa, 2003, 172(1), 1-12. http://dx.doi.org/10.11646/zootaxa.172.1.1.

PINTO, T. K. O., NETTO, S. A., ESTEVES, A. M., CASTRO, F. J. V., NERES, P. F. and DA SILVA, M. C. Free-living freshwater nematodes from Brazil: checklist of genera and regional patterns of diversity. Nematology, 2021, 1-14. https://doi. org/10.1163/15685411-bja10100.

PLATT, H.M. and WARWICK, R.M. A synopsis of the free-living marine nematodes, part I. British enoplids. Cambridge: Cambridge University Press, 1983.

PLATT, H.M. The free-living marine nematodes genus Sabatieria (Nematoda: Comesomatidae). Taxonomic revision and pictorial keys. Zoological Journal of the Linnean Society, 1985, 83(1), 27-28. http://dx.doi. org/10.1111/j.1096-3642.1985.tb00872.x.

SANDULLI, R., MILJUTIN, D., ANGELETTI, L. and TAVIANI, M. Meiobenthos and nematode assemblages from different deep-sea habitats of the Strait of Sicily (Central Mediterranean Sea). Mediterranean Marine Science, 2015, 16(2), 402-412. http://dx.doi.org/10.12681/mms.1145.

SEMPRUCCI, F., COLANTONI, P., BALDELLI, G., SBROCCA, C., ROCCHI, M. and BALSAMO, M. Meiofauna associated with coral sediments in the Maldivian subtidal habitats (Indian Ocean). Marine Biodiversity, 2013, 43(3), 189-198. http://dx.doi. org/10.1007/s12526-013-0146-7.

SMYTHE, A.B., HOLOVACHOV, O. and KOCOT, K.M. Improved phylogenomic sampling of free- 
living nematodes enhances resolution of higher-level nematode phylogeny. BMC Evolutionary Biology, 2019, 19(1), 1-15.

SUGUIO, K. Introdução a sedimentologia. São Paulo: Edgard Bliicher, 1973, pp. 317.

TCHESUNOV, A.V. Order Chromadorida Chitwood, 1933. In: A. SCHMIDT-RAESA, ed. Handbook of Zoology, Gastrotricha, Cycloneuralia and Gnathifera. 2. ed. Hamburg-Germany: De Gruyter, 2014a, pp. 467-486.

TCHESUNOV, A.V. Order Desmodorida De Coninck, 1969. In: A. SCHMIDT-RAESA, ed. Handbook of Zoology: Gastrotricha, Cycloneuralia and Gnathifera. 2. ed. Hamburg-Germany: De Gruyter, 2014b, pp. 399-433.

THAI, T.T., MY YEN, N.T., THO, N. and QUANG, N.X. Meiofauna in the mangrove-shrimp farms ponds, Ca Mau province. Vietnam Journal of Science and Technology, 2017, 55(3), 271. http://dx.doi. org/10.15625/2525-2518/55/3/8410.

TILBERT, S. Diversidade e estrutura da nematofauna em regióes estuarinas tropicais $(-7 \mathrm{oS})$ [Dissertação de Mestrado. Mestrado em Ciências Biológicas]. João Pessoa: Universidade Federal da Paraíba, 2017.

TRAUNSPURGER, W., WILDEN, B. and MAJDI, N. An overview of meiofaunal and nematode distribution patterns in lake ecosystems differing in their trophic state. Hydrobiologia, 2020, 847, 2665-2679. http:// dx.doi.org/ 10.1007/s10750-019-04092-1

TU, N.D. and GAGARIN, V.G. Free-living nematodes from mangrove forest in the Yên River estuary (Vietnam). Inland Water Biology, 2017, 10(3), 266-274. http://dx.doi.org/10.1134/ S1995082917030129.

VANHOVE, S., VERMEEREN, H. and VANREUSEL, A. Meiofauna towards the South Sandwich Trench (750-6300 m), focus on nematodes. Deep-sea Research. Part II, Topical Studies in Oceanography, 2004, 51(14-16), 1665-1687. http://dx.doi. org/10.1016/j.dsr2.2004.06.029.

VANREUSEL, A., FONSECA, G., DANOVARO, R., DA SILVA, M.C., ESTEVES, A.M., FERRERO, T., GAD, G., GALTSOVA, V., GAMBI, C., DA FONSECCA GENEVOIS, V., INGELS, J., INGOLE, B., LAMPADARIOU, N., MERCKX, B., MILJUTIN, D., MILJUTINA, M., MUTHUMBI, A., NETTO, S., PORTNOVA, D., RADZIEJEWSKA, T., RAES, M., TCHESUNOV, A., VANAVERBEKE, J., VAN GAEVER, S., VENEKEY, V., BEZERRA, T.N., FLINT, H., COPlEY, J., PAPE, E., ZEPPILli, D., MARTINEZ, P.A. and GALERON, J. The contribution of deep-sea macrohabitat heterogeneity to global nematode diversity. Marine Ecology (Berlin), 2010, 31(1), 6-20. http://dx.doi.org/10.1111/ j.1439-0485.2009.00352.x.

VENEKEY, V. and MELO, T.P.G.D. Nematodes as indicators of shrimp farm impact on an amazonian estuary (Curuçá, Pará, Brazil). Brazilian Journal of Oceanography, 2016, 64(1), 75-87. http://dx.doi. org/10.1590/S1679-87592016108206401.

VENEKEY, V. Updates on information about freeliving marine nematodes in Brazil: new records and comments on problems in taxonomic studies. Zootaxa, 2017, 4337(1), 38-72. http://dx.doi. org/10.11646/zootaxa.4337.1.2. PMid:29242430.

VENEKEY, V., FONSECA-GENEVOIS, V. and SANTOS, P.J. Biodiversity of free-living marine nematodes on the coast of Brazil: a review. Zootaxa, 2010, 2568(1), 39-66. http://dx.doi.org/10.11646/ zootaxa.2568.1.2.

WALKLEY, A. and BLACK, I. A. An examination of the Degtjareff method for determining soil organic matter, and proposed modification of the chromic acid titration method. Soil Science, 1934, 37(1), 29-38. http://dx.doi.org/10.1097/00010694193401000-00003.

WARWICK, R.M., PLATT, H.M. and SOMERFIELD, P.J. Free-living marine nematodes. Part III. British Monhysterids. Synopses of the British Fauna (New Series). Shrewsbury: The Linnean Society of London and The Estuarine and Coastal Science Association, 1998, 296 p.

YANG, P., GUO, Y., CHEN, Y. and LIN, R. Four new free-living marine nematode species (Sabatieria) from the Chukchi Sea. Zootaxa, 2019, 4646(1), zootaxa.4646.1.2. http://dx.doi.org/10.11646/ zootaxa.4646.1.2. PMid:31717025.

ZHANG, Z.Q. Animal biodiversity: an update of classification and diversity in 2013. In: ZHANG, Z.Q., ed. Animal Biodiversity: An Outline of Higher-level Classification and Survey of Taxonomic Richness (Addenda). Zootaxa, 2013, 3703(1), 5-11. https://doi.org/10.11646/zootaxa.3703.1.3.

ZULLINI, A. Identification Manual for Freshwater Nematode Genera. Italian: Università di Milano Bicocca, 2010, 112 p.

Received: 25 June 2020

Accepted: 21 May 2021

Associate Editors: Irineu Bianchini Junior, Antonio Fernando Monteiro Camargo. 